\title{
Benthic foraminiferal variability on a monthly scale in a subtropical bay moderately affected by urban sewage
}

\author{
LETICIA BURONE ${ }^{1}$, PAULO VALENTE ${ }^{2}$ ANA MARIA S. PIRES-VANIN ${ }^{1}$, SILVIA \\ HELENA DE MELLO E SOUSA ${ }^{1}$, MICHEL M. MAHIQUES ${ }^{1}$ and ELISABETE BRAGA ${ }^{1}$ \\ ${ }^{1}$ Instituto Oceanográfico da Universidade de São Paulo, Pça do Oceanográfico 191, Cidade Universitária, \\ 05508-900 São Paulo, SP, Brazil.E-mail: lburone@io.usp.br; lburone@fcien.edu.uy \\ 2 Instituto de Física, Universidade de São Paulo, Caixa Postal 66318, 05315-970, São Paulo, SP, Brazil.
}

SUMMARY: Benthic foraminifera were sampled monthly during a one-year period in order to examine their biological response to the environmental factors in the Ubatuba Bay (northern coast of São Paulo State, Brazil). The area is a popular tourist destination with a population that varies during the year, as does the untreated sewage carried into the bay by the rivers. Four sites were analysed. Each station is near one of the rivers that discharge into the bay. Biological data were analysed with multivariate and univariate techniques. The influence of the abiotic parameters on the foraminiferal fauna was inferred through statistical methods and time correlation functions. Geochemical and populational parameter differences allowed the sites to be separated into two groups according to their stress conditions. One group was dominated by Ammonia tepida-a herbivore species-and showed higher densities indicating a more productive and less contaminated location. The other one was dominated by Buliminella elegantissima - a detritivore species. Species diversity did not seem to be a good indicator of environmental health in this area due to the low densities and the high dominance of few species. Nevertheless, density and richness were used as evidence of local productivity and environmental conditions. Quasi-azoic moments related to the high degree of contamination were observed. Anthropogenic effects were stronger in the austral summer period, when sewage input through the rivers increases due to mass tourism.

Keywords: benthic foraminifera, time series, environmental quality, monthly scale, organic pollution, Ubatuba, Brazil.

RESUMEN: ESTUDIO DE FORAMINÍFEROS BENTÓNICOS EN ESCALA MENSUAL EN UNA BAHÍA SUBTROPICAL MODERADAMENTE AFECTADA POR EFLUENTES URBANOS. - Fueron analizados foraminíferos bentónicos en cuatro estaciones muestreadas mensualmente con la intención de investigar la respuesta biológica a los factores ambientales en la Ensenada de Ubatuba (costa noreste de São Paulo, Brasil). El área es un importante local turístico cuya población fluctúa a través del año y recibe efluentes no tratados a través de los ríos que en ella desembocan. Fueron analizados cuatro locales. Cada estación se encuentra localizada próxima a uno de los cuatro ríos que desembocan en la bahía. Los datos biológicos fueron analizados con técnicas uni y multivariadas. La influencia de los parámetros abióticos sobre la fauna de foraminíferos fue inferida a través de métodos estadísticos y de funciones de correlación temporal. Parámetros geoquímicas y poblacionales permitieron distinguir dos grupos de estaciones que reflejan las condiciones de estrés local. Uno de los grupos estuvo dominado por Ammonia tepida -especie herbívora- y se mostró más productivo y menos contaminado. El otro local estuvo dominado por Buliminella elegantissima -especie detritívora. La diversidad especifica no se mostró un buen indicador de la salud ambiental en esta región debido a las bajas densidades y a la alta dominancia de unas pocas especies. Sin embargo, la densidad y riqueza pudieron ser utilizadas como evidencias de la productividad local y condiciones ambientales. Fueron observados momentos casi azoicos relacionados con el alto grado de contaminación. Los efectos antropogénicos fueron mayores durante el período de verano austral, cuando la entrada de deshechos domésticos a través de los ríos aumenta como consecuencia del incremento del turismo.

Palabras clave: foraminíferos bentónicos, series temporales, calidad ambiental, escala mensual, polución orgánica, Ubatuba, Brasil. 


\section{INTRODUCTION}

In coastal ecosystem sediment, the contaminants that are derived from human activities usually reach concentrations capable of causing adverse biological effects. As a rule, urbanised littoral areas receive effluent discharges, resulting in the contamination of water, sediment and the biota. This in turn may affect human health either by direct contact or through the food chain. Within aquatic ecosystems, the benthic environment plays an important role as an efficient natural trap for several substances, and it is also a natural regulator of the sedimentary biogeochemical processes. Bottom sediments are a source of nutrients for the water column above them, leading to benthic-pelagic coupling and influencing primary productivity (Jorgensen, 1996). Therefore, sediments may act either as a sink or as a source of contaminants in these ecosystems.

Benthic organisms have traditionally been used to study the impact of pollution and human activities on marine environments (Pearson and Rosenberg, 1978). Among the taxa used for assessing anthropogenic effects, benthic foraminifera are one of the preferred groups because of their typically high abundance and diversity in marine sediments, their small size and high preservation potential (Alve, 1991; Yanko et al., 1994), and their high sensitivity to environmental impact and environmental change. Information about factors that control the development of foraminiferal assemblage is essential, not only for biologists but also for palaeontologists who use foraminifera as tools for the reconstruction of environmental changes in the past. Studies of the pollution effects on benthic foraminifera and of the possible use of these organisms as proxies were initiated by Resig (1960) and Watkins (1961), although pollution effects on foraminifera had been mentioned earlier by Zalesny (1959). Throughout the last two decades, several studies dealing with benthic foraminifera as bioindicators of coastal pollution have been carried out (review in Boltovskoy et al., 1991; Alve, 1995; Yanko et al., 1999; Scott et al., 2001). According to Armynot du Châtelet et al. (2004) most of the literature describes highly polluted environments but, despite their large distribution, little attention has been paid to the abundant moderately polluted estuarine environments. This is probably due to their high complexity because of the dual effect of normal and anthropogenic stresses.
In an earlier work, Burone and Pires-Vanin (2006) studied the benthic foraminifera from the Ubatuba Bay, a semi-enclosed bay on the southern Brazilian coast, analysing 40 sediment samples (collected in a period of less than a week) in order to investigate the relationship between geological and physicochemical parameters and biological data. Through multivariate analysis it was possible to recognise three different sub-environments characterised by their foraminiferal associations. A positive gradient of diversity outward from the bay (among other factors) was observed, indicating that the inner portion of the bay showed the most stressed conditions, and especially a very low population near the da Lagoa and Grande de Ubatuba Rivers. The authors correlated this lowering of foraminiferal population with the river water quality and concluded that this type of sewage probably includes toxins that inhibit foraminiferal population growth. Ubatuba is a town which attracts a great number of tourists and its population shifts yearround, as does the untreated sewage carried into the bay by the rivers. This is the basic motivation for a time-series study and may be seen as the starting point of this work.

Shallow coastal habitats and estuarine regions are considered dynamic environments characterised by high fluctuations in abiotic parameters and subject to continuous disturbance (Turner et al., 1995; Bricker et al., 2003). This natural variability may be a major source of stress to organisms, but the input of nutrients, organic matter and pollutants derived from anthropogenic activities may alter environmental conditions, producing faunal changes different from those expected due to natural variability alone. According to CETESB (1996) and Burone et al. (2003), large amounts of untreated sewage from Ubatuba City are introduced into the Ubatuba Bay, especially through the Grande de Ubatuba and da Lagoa Rivers. Furthermore, Muniz (2003) classified the inner region of the Ubatuba Bay as a moderately contaminated region based on heavy metal concentration.

Time-series and population dynamics studies are important to better distinguish between natural and anthropogenic stress on the foraminiferal fauna. However, due to the intensive work required by time series, there are relatively few temporal studies on benthic foraminiferal fauna in the literature. A list of such studies is presented in Murray and Alve (2000).

The main objective of this work is to examine the temporal evolution of the biological response of the 
benthic foraminifera to the environmental parameter changes. Emphasis is given to a comparison of the examined sites.

\section{MATERIALS AND METHODS}

\section{Study Area}

The Ubatuba Bay is situated on the northern coast of São Paulo State, Brazil $\left(23^{\circ} 25^{\prime}-23^{\circ} 27^{\prime} \mathrm{S}\right.$ and $45^{\circ} 01^{\prime}-45^{\circ} 03^{\prime} \mathrm{W}$ ), forming an area of approximately $8 \mathrm{~km}^{2}$. Water depths vary from 4 to $16 \mathrm{~m}$ (see Fig. 1). It faces eastward, and is protected from southerly and southwesterly waves arising from the open sea. It has an outlet between Ponta do Respingador and Ponta Grossa. In terms of water depth, the bay may be divided into an inner and an outer part. The inner part extends from the coastline to a depth of $10 \mathrm{~m}$, and is characterised by weak hydrodynamic wave energy. The outer part lies between 10 and $16 \mathrm{~m}$ depth and is strongly influenced by the currents and waves from the open sea. Water circulation is clockwise, with the inflow coming from the south.

The input of fluvial sediment is strongly dependent on rainfall regimes, leading to a higher contribution during the summer (Mahiques et al., 1998). Four rivers (Acaraú, da Lagoa, Grande de Ubatuba and Indaiá) discharge into the bay and greatly influence its water quality (CETESB, 1996, 2000; Burone, 2002; Burone et al., 2003, Abessa and Burone, 2003), especially during the summer and the rainy periods, when a vast amount of untreated sewage is released from the nearby town of Ubatuba. As mentioned above, Ubatuba is extremely popular for tourists (with a population of 66,448 inhabitants and 5 times as many during the vacation periods). Therefore, it is affected by increasing amounts of organic pollutants caused by the fast growth of tourism in the region, which has not been accompanied by the development of adequate sewage treatment. As expected, the innermost portion is highly affected by these anthropogenic effects, so in this work we concentrate our analysis on this part of the bay.

As for sedimentological features, the sea-bottom is covered by very fine sand with smaller amounts of silt and clay, and a moderate to high organic matter content (Burone et al., 2003). The Ubatuba Bay is affected by heavy metals, hydrocarbons, and faecal

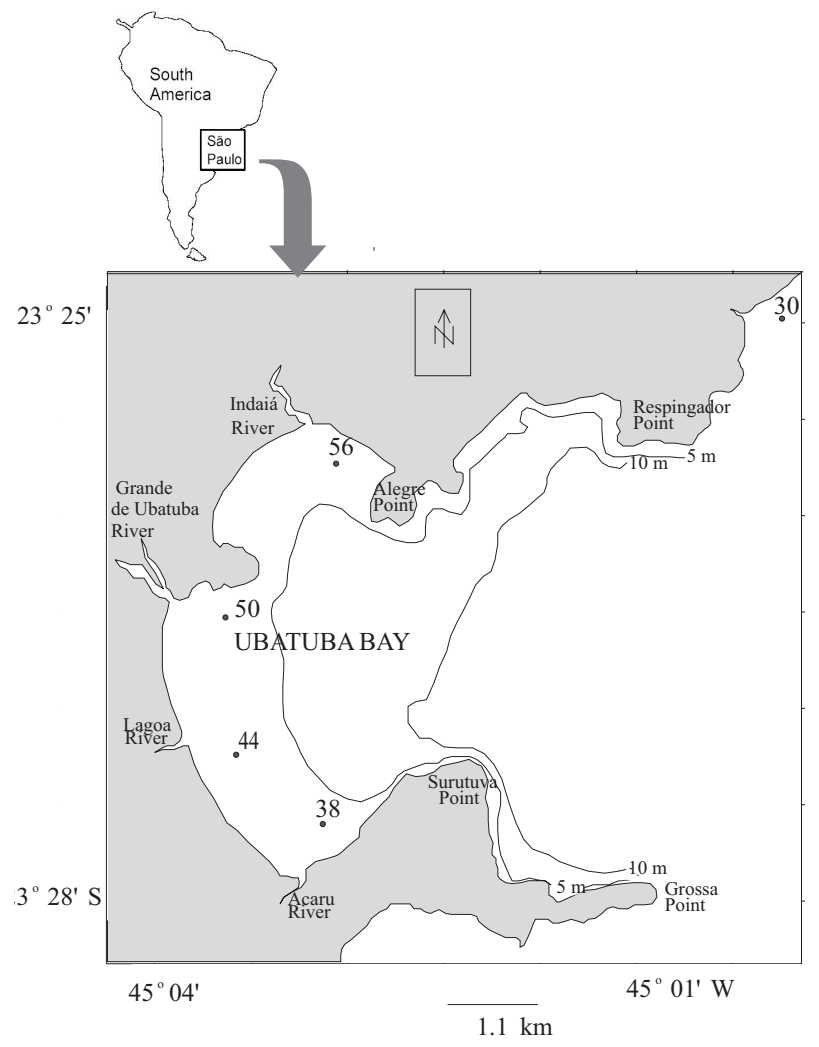

FIG. 1. - Study area map with the 4 sampling stations (black dots).

sterols, and has been classified as a moderately polluted area (Muniz, 2003).

\section{Choice of sampling sites}

From the preliminary spatial faunal studies carried out in the Ubatuba Bay by Burone and PiresVanin (2006), four sites-out of 40 stations initially analysed-were selected for temporal study (Fig. 1). Each of them is located close to a river mouth in the inner part of the bay, according to the following: Station 38 for River Acaraú; Station 44 for River da Lagoa; Station 50 for River Grande de Ubatuba; and Station 56 for the Indaiá River. As previously observed (Burone, 2002; Burone and Pires-Vanin, 2006), Stations 38 and 56 showed the highest densities of foraminifera represented basically by the species Ammonia tepida, as well as the highest number of abnormal tests. Stations 44 and 50 were chosen due to their opposite biological responses, and showed the lowest individual densities. In these cases Ammonia tepida was not the dominant species and Buliminella elegantissima turned out to be more important. 


\section{Sampling procedure}

Sampling was performed monthly at Stations 38, 44, 50 and 56 from October 1998 to October 1999. Sediment samples were taken with a KajakBrinkurst corer sampler $(10 \mathrm{~cm}$ internal diameter, penetrating the sediment by gravity) on board the research vessel Veliger II.

To study the living benthic foraminiferal fauna, the uppermost $3 \mathrm{~cm}$ of the core was removed, forming a volume of about $230 \mathrm{~cm}^{3}$ per sample. All of the samples had the same volume and all living individuals were sorted out. In order to differentiate between living and dead foraminifera the material was stained with buffered Bengal Rose dye (1 $\mathrm{g}$ of Bengal Rose in $1000 \mathrm{ml}$ of distilled water) for 48 hours (Walton, 1952). The wet samples were then carefully washed in the laboratory through 0.500 , 0.250 and $0.062 \mathrm{~mm}$ sieves to segregate the size fractions. After drying at $60^{\circ} \mathrm{C}$, the remaining portion in the smaller sieve was submitted to flotation with carbon trichloroethylene. The floated material was transferred to filter paper and air-dried. All the living specimens in each sample were picked and identified following the generic classification of Loeblich and Tappan (1988). Species were classified by their feeding strategy according to Murray (1991).

Separate samples were taken for organic carbon, nitrogen and grain size analysis. Organic carbon and nitrogen were determined using $500 \mathrm{mg}$ of freezedried and weighted sediment. The samples were decarbonated with a $1 \mathrm{M}$ solution of hydrochloric acid, washed 3 times with deionised water, freezedried and then analysed in a LECO CNS 2000. Granulometric composition was analysed using a Malvern 2000 low-angle laser light scattering (LALLS) instrument, and the size intervals were classified using the Wenthworth scale (Wentworth 1922 in Suguio, 1973).

To study pore water ammonium $\left(\mathrm{NH}_{4}{ }^{+} \mathrm{pw}\right)$ and phosphate $\left(\mathrm{PO}_{4}{ }^{3-} \mathrm{pw}\right)$ ion concentrations, the sediment was placed inside a glove box installed on board, filled with inert gas $\left(\mathrm{N}_{2}\right)$ and completely sealed immediately after sampling. Then, the sediment was stored in plastic bottles and kept at a temperature of $-20^{\circ} \mathrm{C}$ until the pore water was extracted in the laboratory. The extraction was performed by sediment centrifugation and all of the analyses were made in oxygen-free atmospheres as described by Burone et al. (2005). The ammonium analysis fol- lowed the traditional colorimetric method described in Tréguer and Le Corre (1975) and phosphate was determined colorimetrically as presented in Grasshoff et al. (1983).

The chlorophyll $a(\mathrm{Chl} a)$ content of surface sediments was determined according to Lorenzen (1967) and Strickland and Parson (1968). Nevertheless, its composition is basically constant over the year, so it was disregarded in the temporal analysis.

In addition to the sediment sampling, bottom water samples were taken by means of Nansen bottles to study the following variables: temperature (T), dissolved oxygen content $\left(\mathrm{O}_{2}\right)$, salinity (Sal), $\mathrm{pH}$, and ammonium $\left(\mathrm{NH}_{4}{ }^{+} \mathrm{bw}\right)$ and phosphate $\left(\mathrm{PO}_{4}{ }^{3-}\right.$ bw) concentrations. The temperature of the bottom water was measured by means of reversing thermometers. Salinity was determined in the laboratory by a salinometer using a PSU scale; $\mathrm{pH}$ was measured on board using a Digimed model DM-2 pHmeter. Dissolved oxygen content was measured by the Winkler titration method (Grasshoff et al., 1983). To determine the nutrients in the bottom water, the samples were frozen to be analysed in the laboratory. The phosphate concentration was determined using a Technicon Auto-Analyzer II according to the recommendations described by Grasshoff et al. (1983), and the ammonium concentration was determined following the method described by Tréguer and Le Corre (1975).

\section{Data analysis}

In the laboratory all the living foraminiferal individuals were counted. The data were analysed using univariate and multivariate methods. Diversity $\left(H^{\prime}\right)$ was calculated on a natural logarithmic basis $(\ln x)$ by the Shannon-Wiener index (Shannon and Weaver 1963); the evenness ( $J^{\prime}$ ) was calculated according to Pielou (1975); and species richness $(S)$ was determined as the total number of species.

A principal component analysis (PCA) was carried out for the ordination of sample locations for the abiotic factors. A first matrix (previously normalised and centred) was constructed using the total of variables measured. However, in order to avoid redundancy and perform a more realistic ordination, the variables with a low percentage of contribution were eliminated. Therefore, a second matrix was obtained using a total of 12 variables: total organic carbon (C), fine sand (FS), very fine sand (VFS), 
silt, Salinity, $\mathrm{O}_{2}, \mathrm{pH}$, chlorophyll $a(\mathrm{Chl} a)$, ammonium dissolved in the water column $\left(\mathrm{NH}_{4}{ }^{+} \mathrm{bw}\right)$, phosphate dissolved in the water column $\left(\mathrm{PO}_{4}{ }^{3-b w}\right)$, ammonium dissolved in the pore water $\left(\mathrm{NH}_{4}{ }^{+} \mathrm{pw}\right)$ and phosphate dissolved in the pore water $\left(\mathrm{PO}_{4}{ }^{3-p w}\right)$.

As a first approximation for the analysis of the relation between the biotic and abiotic variables, a Pearson correlation analysis was performed considering $\mathrm{p}<0.05$ as the significant level.

In order to analyse the temporal response of the foraminiferal community, we applied several statistical tools. At first we calculated the autocorrelation coefficient for each station, defined by

$$
R(\tau)=\frac{\sum_{i=1}^{N-\tau}\left(y_{i}-\bar{y}\right)\left(y_{i+\tau}-\bar{y}\right)}{\sum_{i=1}^{N-\tau}\left(y_{i}-\bar{y}\right)^{2}},
$$

where $y_{i}$ is the data in the time $i, \bar{y}$ is the mean value (averaged through the year), $y_{i+\tau}$ is the data in the time $i+\tau$ and $\tau$ is a lag time. We calculated the $R(\tau)$ coefficient for each data set (biotic and abiotic parameters) and each station. Equation 1 was referred to as a Time Series Analysis (Wilson and Dawe, 2006) and proved to be a useful tool for evidencing periodic behaviours in foraminiferal communities. The time profile of the $R(\tau)$ function reveals the periodicity of the corresponding data set, if such periodicity exists. Similarly, we also calculated the cross-correlation function for some chosen pairs of variables, defined by

$$
R_{y z}(\tau)=\frac{\sum_{i=1}^{N-\tau}\left(y_{i}-\bar{y}\right)\left(z_{i+\tau}-\bar{z}\right)}{\sqrt{\sum_{j=1}^{N}\left(y_{i}-\bar{y}\right)^{2} \sum_{j=1}^{N}\left(z_{i}-\bar{z}\right)^{2}}},
$$

where $y$ and $z$ are two different variables. Because $\tau$ is always a positive lag time, we chose $y$ with care as an independent parameter (usually an abiotic one) and $z$ as the dependent one. Thus, $R_{y z}(\tau)$ may give an estimate of the response time for the variable $z$ as a result of the action of $y$. For $\tau=0, R_{y z}(\tau=0)$ corresponds to a usual linear correlation.

The possible seasonal environment effect and its biotic response over time were analysed using a nonmetric multi-dimensional ordination (nMDS; Kruskal and Wish, 1978). This nMDS ordinates groups of stations with similar foraminiferal fauna structure and was performed using the abundance similarity matrix, where the Bray-Curtis similarity index was used (Bray and Curtis, 1957). Four seasonal matrix data were constructed, one for each season according to the definition: Spring (October, November and December), Summer (January, February and March); Autumn (April, May and June); and Winter (July, August and September). Data were transformed by the square-root transformation.

Once the temporal data had been obtained we calculated the annual average values of the population parameters $\left(\bar{H}^{\prime}, \bar{J}, \bar{S}\right.$ and $\left.\bar{D}\right)$. Since $\bar{J},, \bar{S}$ and $\bar{D}$ were calculated using simple arithmetic averages, $\bar{H}$ ' was obtained with a geometric average, weighted by richness (Burone and Pires-Vannin, 2006)

$$
\overline{H_{k}^{\prime}}=\frac{\sum_{i=1}^{13} H_{k i}^{\prime} S_{k i}}{\sum_{i=1}^{13} S_{k i}},
$$

where $H_{k i}^{\prime}$ and $S_{k i}$ are diversity and richness of the station $k$ at month $i$, respectively. This annual mean gives a good characterisation of each studied site.

To perform uni- and multivariate techniques we used the Multivariate Statistical Package (MVSP) (Kovach, 1999) and the PRIMER package (version 5.0, Clarke and Warwick, 2001).

\section{RESULTS}

\section{Environmental variables}

Water temperature (Fig. 2) ranged from 20.3 to $30.3^{\circ} \mathrm{C}$ and showed maximum values in summer and minimum ones in winter, with an expected seasonal pattern. Salinity values ranged between 31.5 and 35 . On average, the lowest values were registered at Station 50, as a consequence of the Grande de Ubatuba River which, among the four tributary bay rivers, has the highest river discharge. In general, the $\mathrm{pH}$ values lay around 8.0, revealing slightly basic water. Nevertheless, a highly acid condition $(\mathrm{pH} \cong$ 6.0) was found at Station 50 for November, December and January. This may be related to the low oxygen concentration registered at this station ( 3.2 and $3.9 \mathrm{ml} / \mathrm{l}$ ) and to the maximum carbon concentration shown below $1.44 \%$.

The nutrient concentrations are presented in Figure 3 . The $\left(\mathrm{NH}_{4}{ }^{+} \mathrm{bw}\right)$ shows an approximately 
780 - L. BURONE et al.
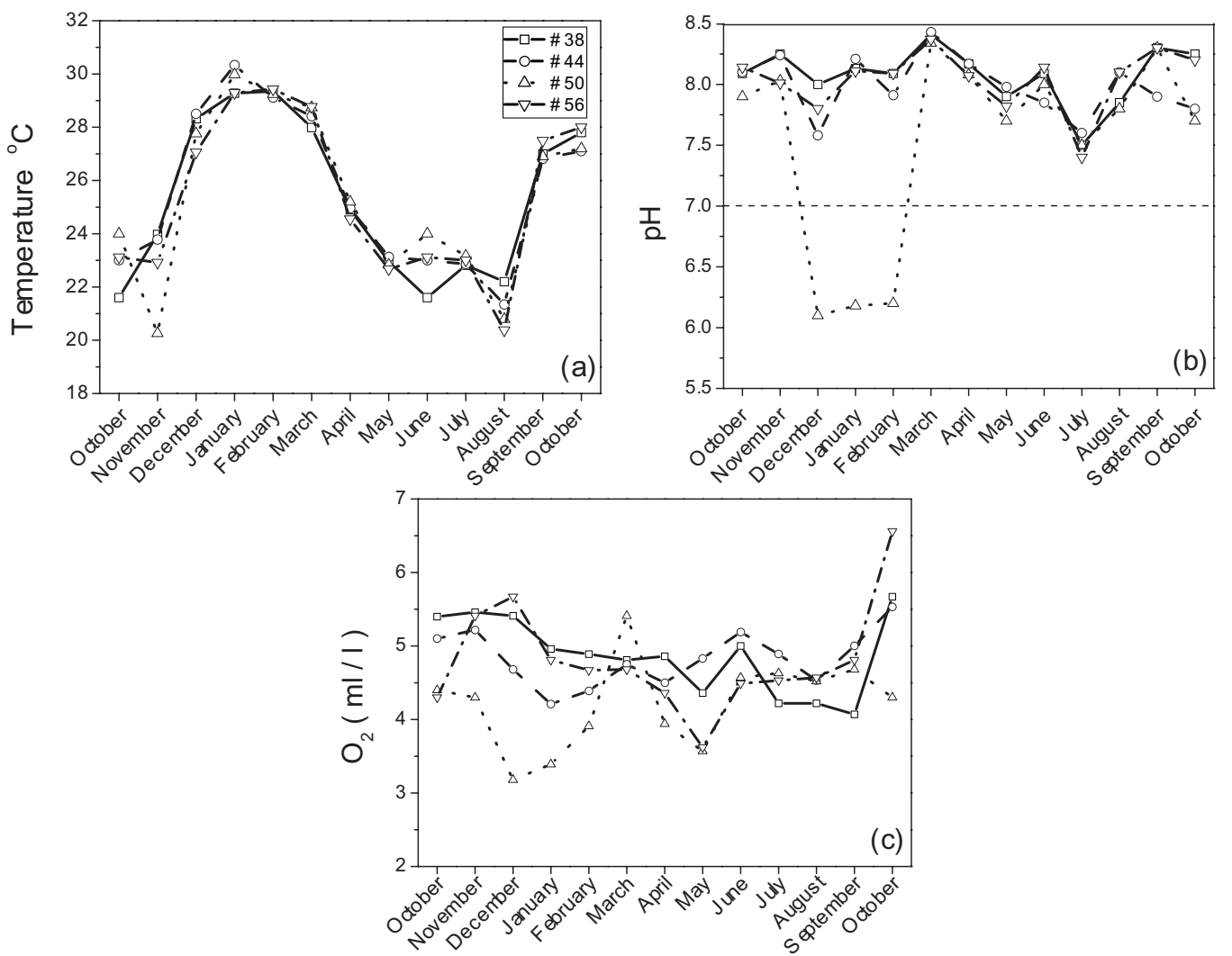

FIG. 2. - Time distribution of Temperature (a), pH (b) and Oxygen concentration (c) for the four analysed stations. Legend is shown in (a).
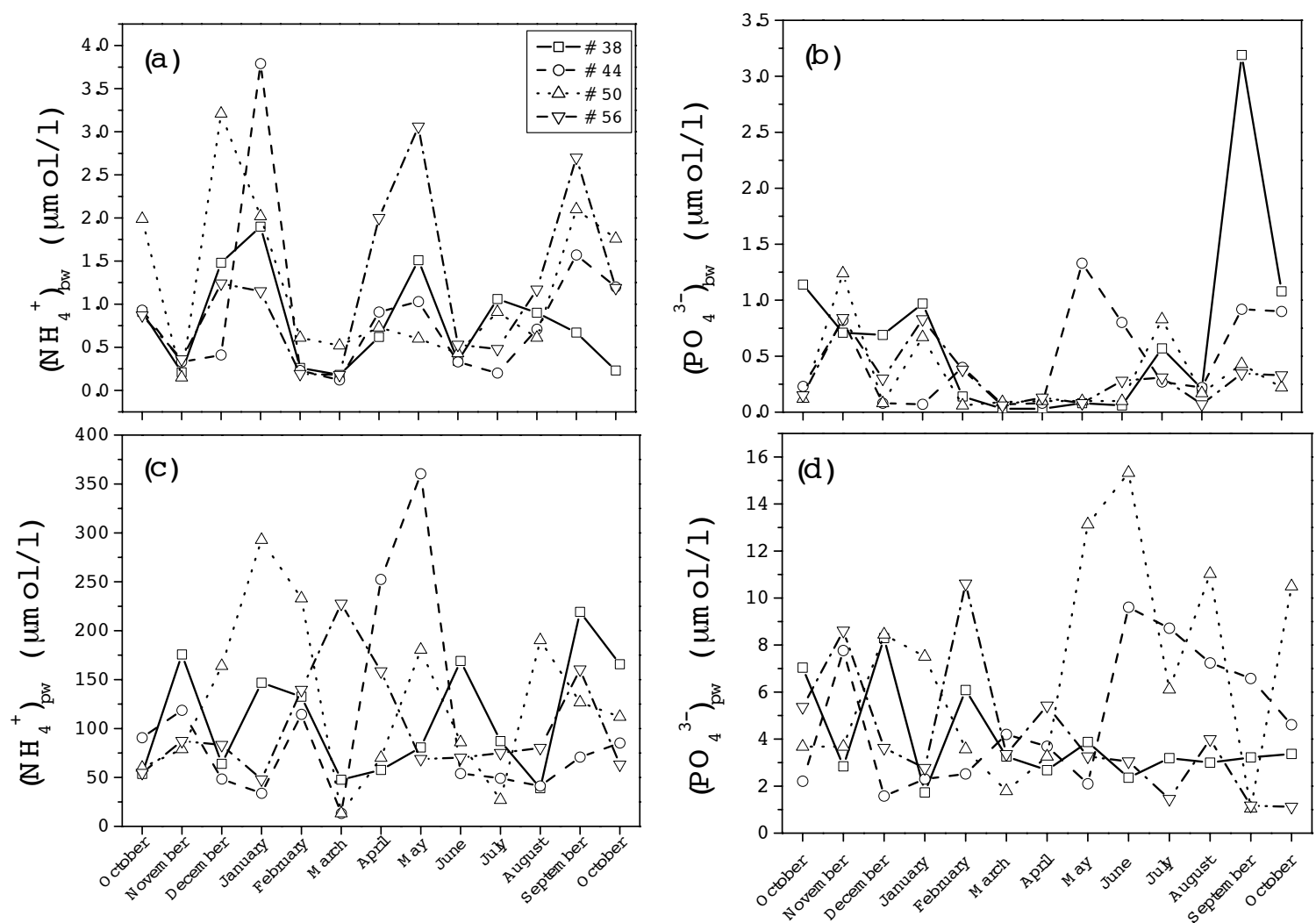

FIG. 3. - Time distribution of nutrient concentration for the four analysed stations. $\mathrm{NH}_{4}^{+} \mathrm{bw}$ (a), $\mathrm{PO}_{4}^{-3} \mathrm{bw}$ (b) $\mathrm{NH}_{4}^{+} \mathrm{pw}$ (c) and $\mathrm{PO}_{4}^{-3} \mathrm{pw}(\mathrm{d})$. Legend is shown in (a). 

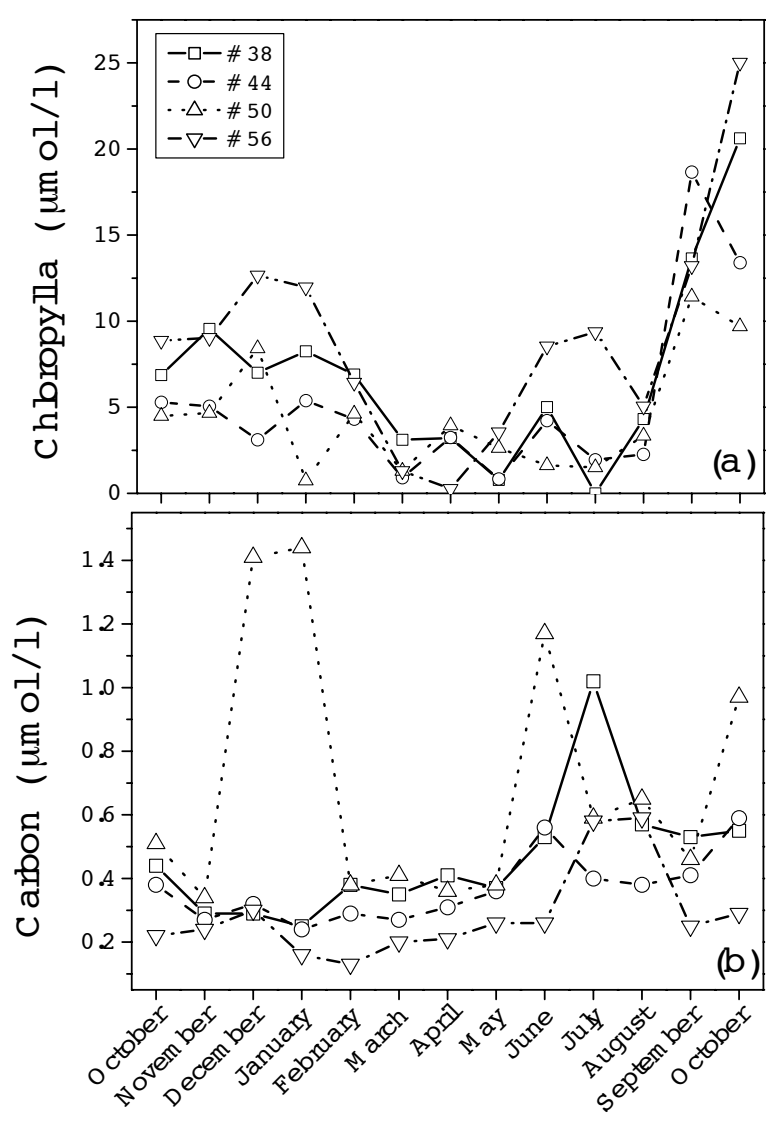

FIG. 4. - Time distribution of Chlorophyll $a$ (a), and Carbon (b) concentrations for the four analysed stations. Legend is shown in (a). periodic behaviour, reaching its maxima in December/January, April/May and September, while $\left(\mathrm{PO}_{4}{ }^{3-\mathrm{bw}}\right)$ has a more limited variation, although very low values are present in March/April and at two accentuated peaks in May (for Station 44) and September (for Station 38). As expected, the $\left(\mathrm{NH}_{4}{ }^{+} \mathrm{pw}\right)$ and $\left(\mathrm{PO}_{4}{ }^{3} \mathrm{pw}\right)$ concentrations were at least one order of magnitude greater than those obtained in the water column. In Figure 4, the Chlorophyll $a$ and total organic carbon variation over the year are displayed. We observed a decrease in Chl $a$ at the end of summer and during autumn and a subsequent increase at the beginning of spring. The $\mathrm{C}$ concentration was almost constant over the year, with some discrepancies at Stations 50 (especially in Jan/Dec) and 44.

\section{PCA analysis}

The PCA analysis (Fig. 5) allowed two main groups of sampling stations to be distinguished according to the different environmental conditions within the study area. The first and second components together explained $51 \%$ of the total data variance, $35 \%$ being explained by the first component. The first group (G I) was formed by the samples corresponding to Stations 44 and 50 and the second group (G II) by the samples corresponding to

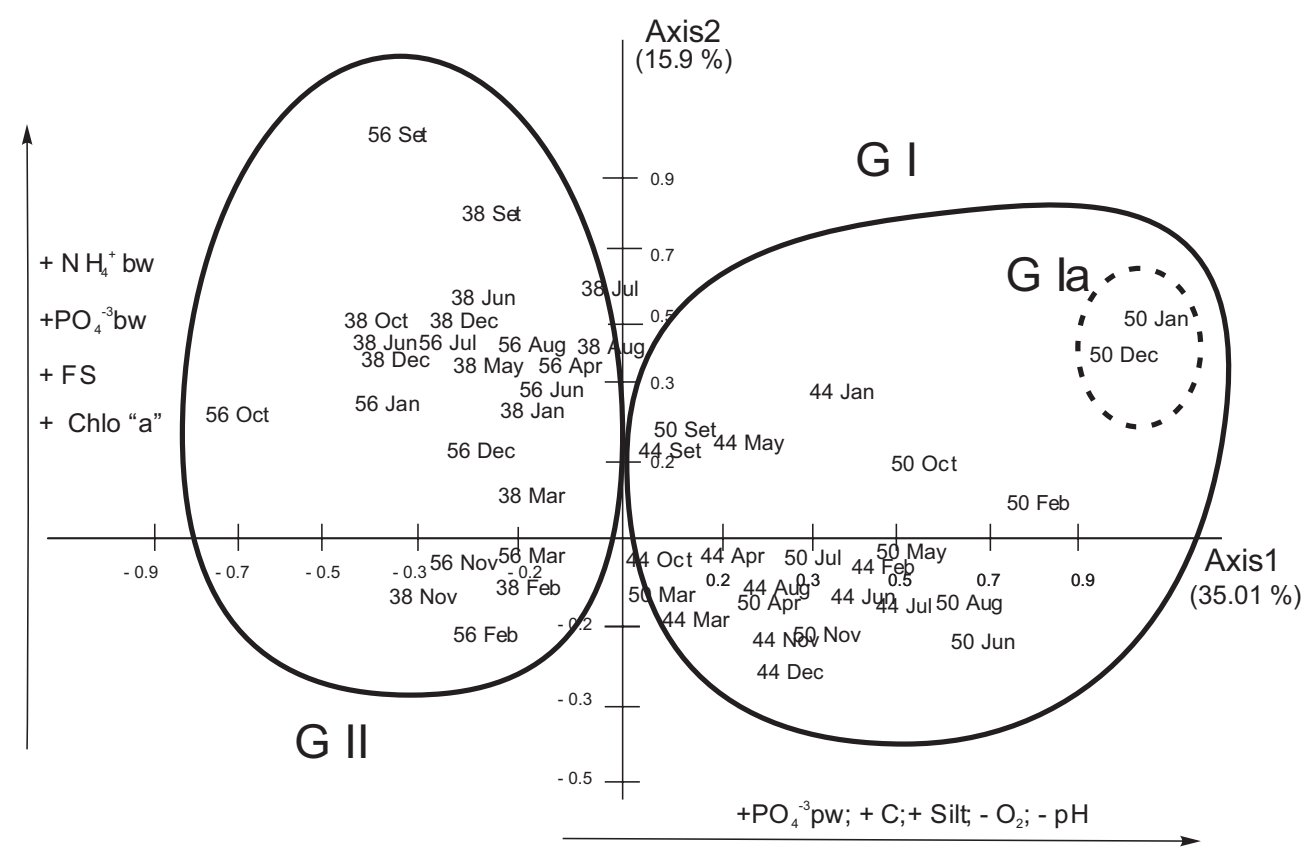

FIG. 5. - PCA ordination diagram of sampling based on the selected variables measured. The two main groups (Groups G I and G II) and the subgroup G Ia are delimited. 
TABLE 1. - Species distribution of living foraminifera at each station throughout the year. SD: standard deviation; AA: annual average. FS: Feeding Strategy. H: herbivore; D: detritivore; S: suspensivore. Sample volume: $230 \mathrm{~cm}^{3}$.

\begin{tabular}{|c|c|c|c|c|c|c|c|c|c|}
\hline \multirow[b]{2}{*}{ Foraminifera / Stations } & \multirow[b]{2}{*}{ FS } & \multicolumn{2}{|c|}{ \#38 } & \multicolumn{2}{|c|}{ \#44 } & \multicolumn{2}{|c|}{ \#50 } & \multicolumn{2}{|c|}{ \#56 } \\
\hline & & A. A & SD & A. A & SD & A. A & SD & A. A & SD \\
\hline Ammobaculites exiguus & $\mathrm{D}$ & 1.50 & 0.71 & - & - & - & - & - & - \\
\hline Ammonia parkinsoniana & $\mathrm{H}$ & 11.10 & 7.82 & 8.17 & 10.07 & 18.00 & - & 8.50 & 4.32 \\
\hline Ammonia tepida & $\mathrm{H}$ & 598.23 & 441.98 & 11.54 & 62.75 & 69.30 & 106.10 & 752.62 & 648.93 \\
\hline Bolivina compacta & $\mathrm{D}$ & 3.33 & 2.31 & 2.00 & 1.00 & 9.00 & & 3.00 & 1.41 \\
\hline Bolivina doniezi & $\mathrm{D}$ & 3.00 & 2.68 & 2.57 & 2.51 & 2.90 & 1.90 & 1.43 & 0.53 \\
\hline Bolivina ordinaria & $\mathrm{D}$ & 2.00 & 1.41 & 1.67 & 0.58 & 1.50 & 0.70 & 2.00 & - \\
\hline Bolivina pulchella & $\mathrm{D}$ & 1.50 & 0.71 & & & 10.30 & 10.00 & - & - \\
\hline Brizalina striatula & $\mathrm{D}$ & 76.50 & 47.36 & 18.92 & 14.52 & - & - & 15.85 & 11.36 \\
\hline Bulimina marginata & $\mathrm{D}$ & 1.60 & 0.55 & - & - & - & - & 1.86 & 1.46 \\
\hline Bulimina pupoides & $\mathrm{D}$ & 1.00 & 0.00 & - & - & - & - & - & - \\
\hline Buliminella elegantissima & $\mathrm{D}$ & 131.92 & 66.68 & 205.25 & 122.30 & 154.20 & 111.60 & 97.83 & 61.78 \\
\hline Cibicides lobatulus & $\mathrm{S}$ & 1.00 & - & - & - & - & - & - & - \\
\hline Cibicides variabilis & $\mathrm{S}$ & - & - & 1.00 & - & - & - & - & - \\
\hline Discorbis sp. & $\mathrm{H}$ & 1.33 & 0.58 & 1.25 & 0.50 & - & - & 4.33 & 3.08 \\
\hline Discorbis williamnsonii & $\mathrm{H}$ & 1.00 & - & 1.00 & - & - & - & 1.00 & 0.00 \\
\hline Elphidium excavatum & $H / D$ & 7.18 & 9.03 & 1.00 & - & - & - & 5.80 & 7.21 \\
\hline Elphidium poeyanum & $H / D$ & 1.00 & - & - & - & - & - & - & - \\
\hline Fissurina quadricostulata & & 1.00 & - & - & - & - & - & - & - \\
\hline Fursenkoina pontoni & $\overline{\mathrm{D}}$ & 9.83 & 10.15 & 4.43 & 4.47 & 13.50 & 11.00 & 2.33 & 1.53 \\
\hline Gaudryina exilis & $\mathrm{S}$ & 8.75 & 9.03 & - & - & 1.50 & 0.70 & 8.00 & 6.78 \\
\hline Hanzawaia boueana & $\mathrm{S}$ & 1.00 & 0.00 & 18.00 & - & - & - & - & - \\
\hline Haynesina germanica & $\mathrm{H}$ & 7.11 & 7.59 & 2.00 & 1.10 & 1.70 & 0.60 & 14.00 & 16.22 \\
\hline Hopkinsina pacifica & $\mathrm{D}$ & 3.50 & 3.54 & 2.00 & - & 14.00 & 17.00 & 1.00 & - \\
\hline Miliammina fusca & $\mathrm{D}$ & 1.00 & - & - & - & - & - & - & - \\
\hline Nonionella opima & $\mathrm{D}$ & 1.00 & - & 1.50 & 0.71 & - & - & - & - \\
\hline Nonionella pulchella & $\mathrm{D}$ & 1.00 & 0.00 & 1.50 & 0.71 & - & - & - & - \\
\hline Pararotalia cananeiaensis & $\mathrm{H}$ & 3.90 & 3.07 & 30.91 & 53.07 & 102.00 & 195.90 & 25.60 & 31.87 \\
\hline Pseudononion atlanticum & $\mathrm{H}$ & 7.78 & 5.93 & 8.18 & 5.38 & 3.90 & 2.60 & 5.57 & 5.26 \\
\hline Pseudononion grateloupi & $\mathrm{H}$ & - & - & 1.00 & - & 1.00 & - & - & - \\
\hline Quinqueloculina gregaria & $\mathrm{H}$ & 1.00 & - & - & - & - & - & - & - \\
\hline Quinqueloculina milletti & $\mathrm{H}$ & 3.13 & 4.16 & 9.40 & 6.29 & 8.00 & 9.50 & 3.63 & 3.25 \\
\hline Quinqueloculina patagonica & $\mathrm{H}$ & - & - & - & - & 1.00 & - & - & - \\
\hline Quinqueloculina seminula & $\mathrm{H}$ & 7.00 & 10.39 & 4.60 & 3.51 & - & - & 2.00 & - \\
\hline Reophax nana & $\mathrm{D}$ & 1.00 & 0.00 & - & - & 2.00 & - & 3.50 & 0.71 \\
\hline Rosalina sp. & $\mathrm{H}$ & 2.00 & 1.41 & - & - & 2.00 & - & & - \\
\hline Textularia earlandi & $\mathrm{D}$ & - & - & 1.00 & - & 1.00 & - & 2.33 & 1.53 \\
\hline Triloculina cultrata & $H / D$ & - & - & 1.00 & - & - & - & - & - \\
\hline Triloculina subrotunda & $\mathrm{H} / \mathrm{D}$ & - & - & & - & - & - & 1.00 & - \\
\hline Trochammina ochracea & $\mathrm{H} / \mathrm{D}$ & - & - & 1.00 & - & - & - & - & - \\
\hline Uvigerina bifurcata & $\mathrm{D}$ & & - & - & & 2.00 & 0.70 & 1.33 & 0.58 \\
\hline Virgulina rigii & $\mathrm{D}$ & 4.00 & - & 1.25 & 0.50 & - & - & - & - \\
\hline Total & & 10862 & & 4851 & & 4304 & & 12009 & \\
\hline
\end{tabular}

Stations 38 and 56. The first one was positively related to Axis I due to its high concentration of carbon, silt and $\left(\mathrm{PO}_{4}{ }^{3} \mathrm{pw}\right)$, as well as the low oxygen content and $\mathrm{pH}$ values in the bottom water. Within this group it was possible to observe a smaller subgroup (G Ia) formed by the months of December and January of Station 50, which had low $\mathrm{pH}$ values and $\mathrm{O}_{2}$ content. On the other hand, G II was negatively linked with Axis I, due to high concentrations of $\left(\mathrm{NH}_{4}{ }^{+} \mathrm{bw}\right),\left(\mathrm{PO}_{4}{ }^{3-b w}\right)$ and $\mathrm{Chl} a$ in the sediment, and a high fine sand content

\section{Fauna}

A total of 42 species and 32623 individuals of benthic foraminifera were recorded from the 52 samples analysed. The most abundant species was Ammonia tepida, followed by Buliminella elegantissima (Table 1, Fig. 6e, f). However, these species showed differentiated distributions. While the former was dominant at Stations 38 and 56, the latter was dominant at Stations 44 and 50. Density showed the highest values at Stations 56 and 38 , where it reached 2274 and 1791 ips (individuals per sample), respectively, in October 1999.

Total density $(D)$, diversity $\left(H^{\prime}\right)$, richness $(S)$ and evenness $\left(J^{\prime}\right)$ are represented in Figure 6 as a function of time. The highest $S$ values were registered at Station 38 (20 species) during the summer and very low values at Stations 50 (November and December) and 44 (May), with no more than 4 species. $H^{\prime}$ ranged between 0.52 and 2 , with the 

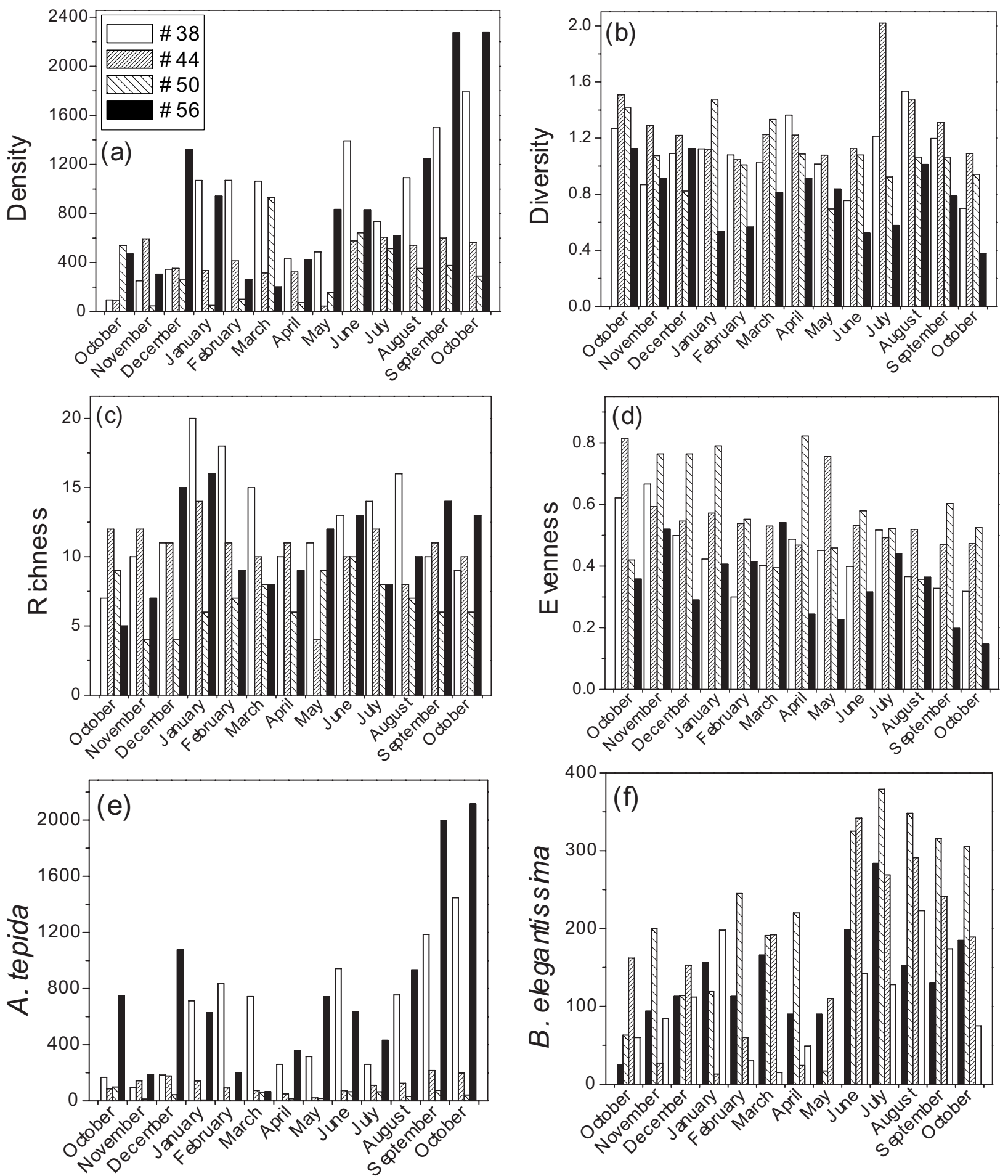

FIG. 6. - Time distribution of the population parameters for the four analysed stations. (a) Density; (b) Diversity; (c) Richness, (d) Evenness (e) Ammonia tepida density and (f) Buliminella elegantissima density. Legend is shown in (a). ips: individual per sample in a volume sample of $230 \mathrm{~cm}^{3}$.

maximum value at Station 44 (in July) and the minimum value at Station 56 (in October 99), but there were no appreciable changes throughout the year. In general, the values of $J$ ' at Stations 38 and 56 were lower than at Stations 44 and 50 due to the high $A$. tepida densities at the first two stations (Fig. 6e). A comparison among the four stations analysed is displayed in Figure 7 with mean annual values for the population variables. It is clear that Stations 44 and 50 showed a response which is opposite to that of 

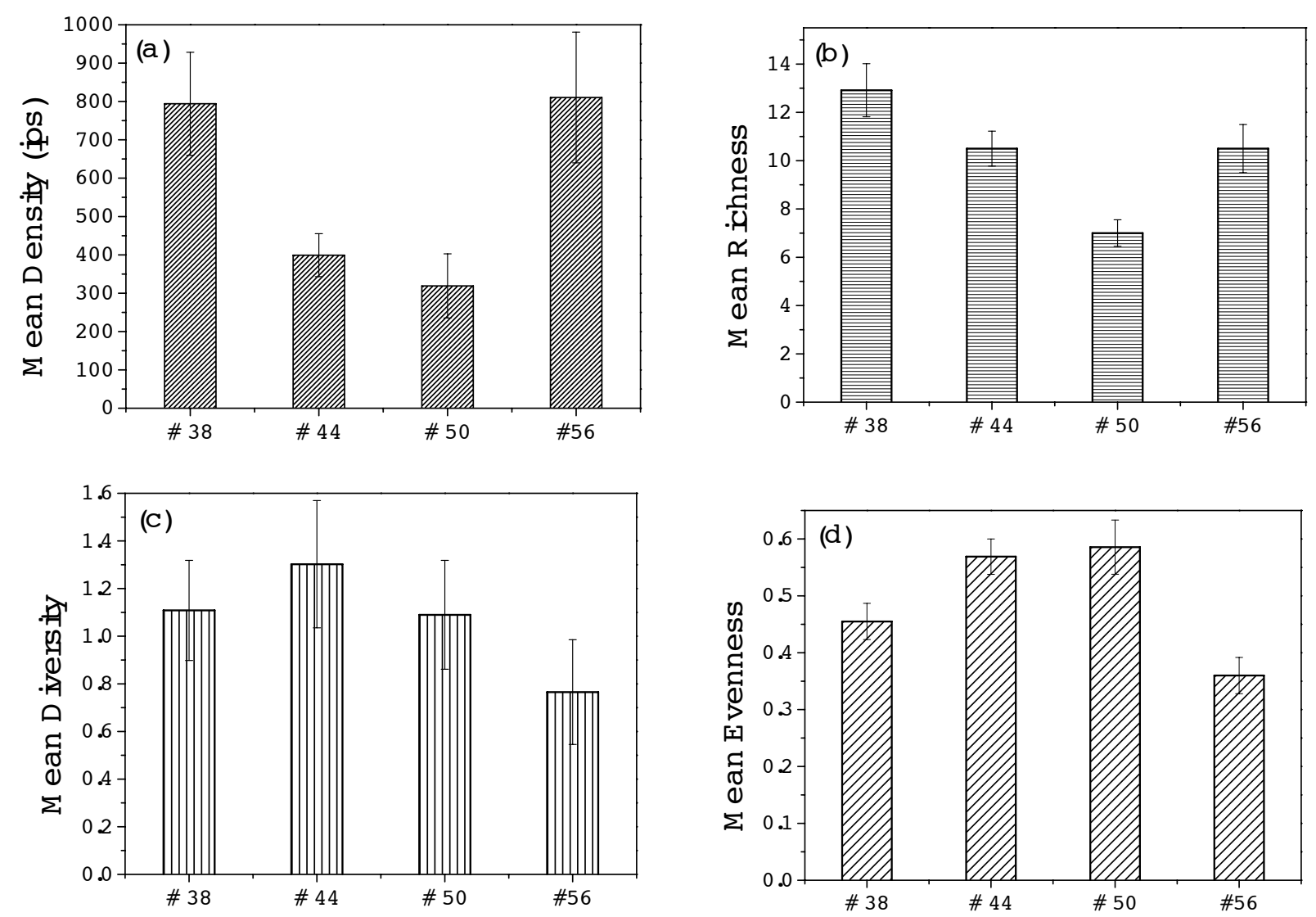

FIG. 7. - Annual average values for the population parameters of the four analysed stations. (a) Density; (b) Diversity; (c) Richness and (d) Evenness. The standard deviations are showed as error bars. ips: individual per sample in a volume sample of $230 \mathrm{~cm}^{3}$.

Stations 38 and 56. An interesting point is that the $\bar{H}$ ' and $\bar{S}$ do not show the same behaviour, due to the dominance of few species at Stations 38 and 56, which is in agreement with $\bar{J}$.

To emphasise the difference in the population dynamics among the analysed sites we divided the total density into herbivores and detritivores (Table 1) and analysed the temporal evolution as a function of the temperature via Equation 2. Suspension feeder individuals were extremely few and thus neglected.

\section{Pearson correlation}

Table 2 shows the Pearson Correlation between the population and the abiotic variables. A high correlation value $(\mathrm{r}=0.6)$ was obtained when we correlated the A.tepida density to the Chl $a$ in the sediment and to $\mathrm{PO}_{4}{ }^{3-b w}$. Other important values were found by correlating the total density to the same abiotic factors. As a general trend, we observed that the pore water nutrients showed a positive correla-

TABLE 2. - Pearson's coefficients of correlation between abiotic factors and population parameters. Significant $(p<0.05)$ correlation coefficients in boldface.

\begin{tabular}{|c|c|c|c|c|c|c|c|}
\hline & $H^{\prime}$ & $J^{\prime}$ & $S$ & $D$ & A. tepida & B. elegantissima & P. cananeiaensis \\
\hline $\mathrm{NH}^{+}{ }_{4} \mathrm{pw}$ & -0.05429 & 0.1915 & -0.311 & -0.1668 & -0.0424 & 0.3456 & -0.216 \\
\hline $\mathrm{PO}_{4}^{-3} \mathrm{pw}$ & 0.143 & 0.165 & -0.2489 & -0.3524 & -0.4065 & 0.2912 & -0.004 \\
\hline $\mathrm{NH}^{+}{ }_{4} \mathrm{bw}$ & -0.0681 & -0.094 & 0.1263 & 0.0651 & 0.1416 & -0.1369 & -0.1137 \\
\hline $\mathrm{PO}_{4}^{-3} \mathrm{bw}$ & -0.3295 & -0.2603 & 0.1169 & 0.5517 & 0.5988 & 0.016 & -0.273 \\
\hline Salinity & -0.0499 & -0.155 & 0.1911 & 0.0803 & -0.189 & -0.2013 & -0.2657 \\
\hline Temp. & 0.1325 & -0.0296 & 0.2469 & 0.0755 & 0.1056 & -0.2202 & 0.1138 \\
\hline $\mathrm{O}_{2}$ & -0.1824 & 0.2996 & 0.2885 & 0.4501 & 0.3633 & 0.1955 & 0.287 \\
\hline $\mathrm{C}^{2}$ & 0.2513 & 0.3078 & -0.238 & -0.1203 & -0.189 & 0.2887 & -0.0379 \\
\hline $\mathrm{pH}$ & -0.2336 & -0.3205 & 0.2452 & 0.3165 & 0.273 & 0.1128 & 0.1226 \\
\hline Chlo a & -0.3327 & -0.3746 & 0.2276 & 0.5743 & 0.61 & 0.039 & -0.1885 \\
\hline
\end{tabular}



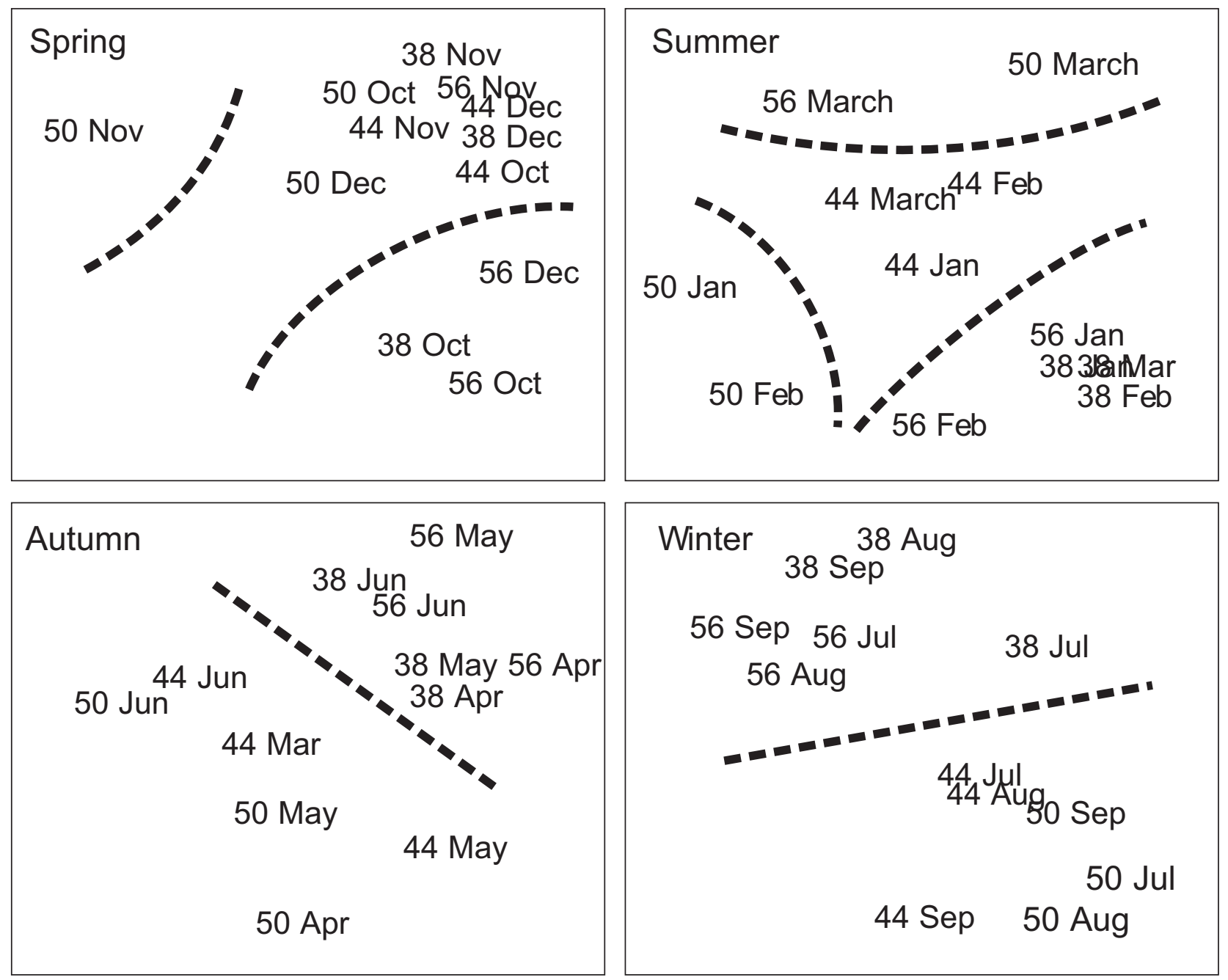

FIG. 8. - nMDS ordinations of the stations in each season (Spring, Summer, Autumn and Winter). Stress of the two dimensional configuration is 0.08 for all cases.

tion with $B$. elegantissima, whereas $\mathrm{PO}_{4}^{3-b w}$ was positively correlated with $A$. tepida. A. tepida was dominant at Stations 38 and 56, while B. elegantissima was dominant at Stations 44 and 50.

\section{nMDS ordination}

The nMDS ordination performed by season allowed different sample groups (Fig. 8) with spatial and temporal environmental gradients to be recognised. In the autumn and winter it was only possible to distinguish two groups by combining Stations 38 and 56 on one side, and 44 and 50 on the other. A dispersive behaviour began in the spring, reaching a maximum in the summer, probably due to the combination of natural environmental changes ( $\mathrm{T}$ and Chl $a$ increases) and anthropogenic factors. To achieve continuous time series, for the nMDS we kept the October 1998 samplings and discarded the October 1999 one.

\section{Autocorrelation}

Using Equation 1, we calculated the autocorrelation function for all measured variables and the most significant results were plotted in Figure 9. These curves show the value of the $R$ for different lag times between 1 and 9 months. The analysis of the temperature graph is useful to illustrate the behaviour of $R(\tau)$. The effect of seasonality was apparent, showing a positive correlation for $\tau=1$ month and an anti-correlation for $\tau$ lying between 4 and 6 months of lag time. In general, the period of the $R(\tau)$ function corresponded to a periodicity that appears in the original data (see Fig. 2). As for temperature, a clear 6-month period was observed, which is an 

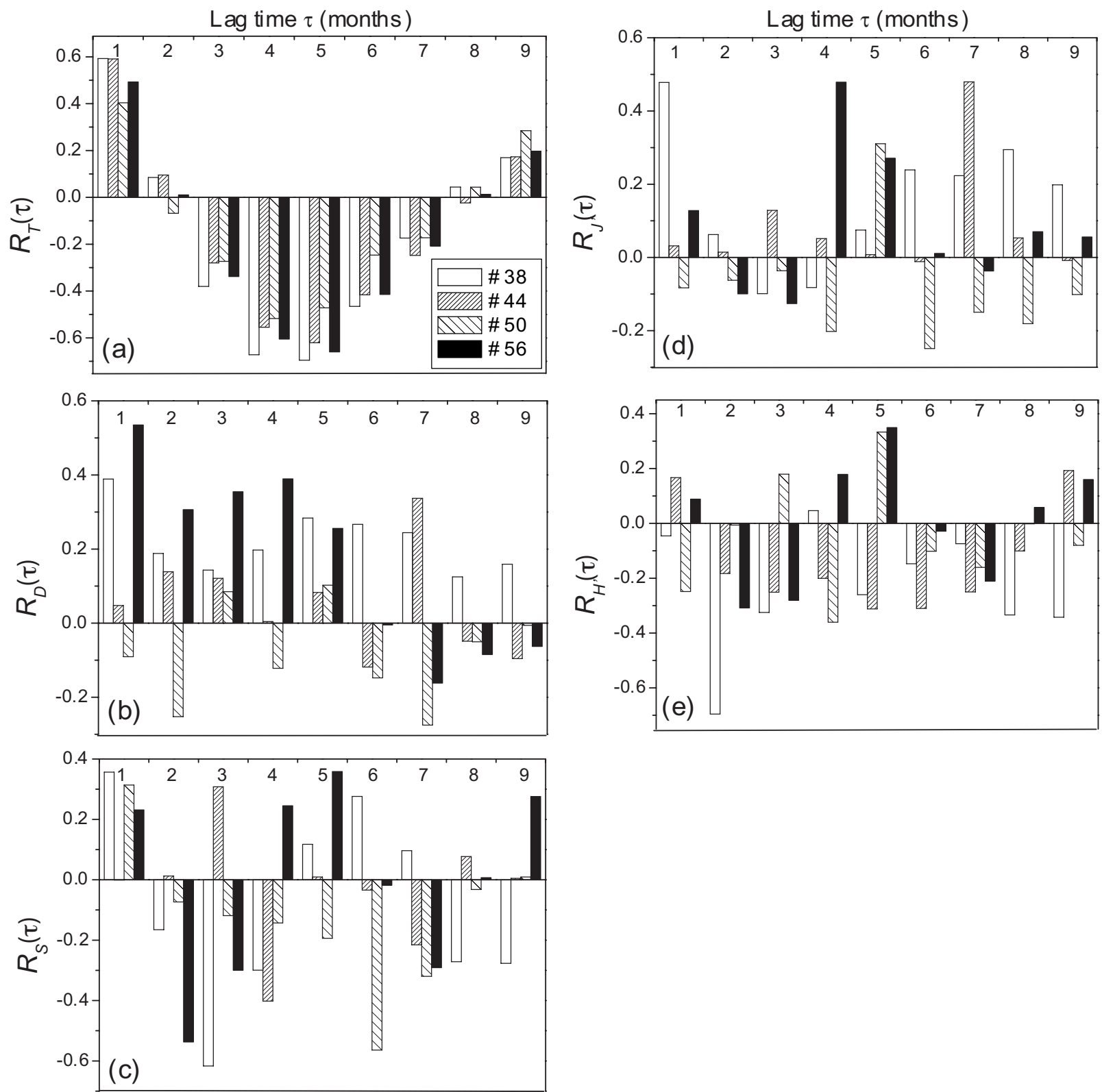

FIG. 9. - Autocorrelation functions - see Eq. (1) in the text - for some chosen variables. (a) Temperature (b) Density; (c) Richness, (d) Evenness and (e) Diversity;. Legend is shown in (a).

obvious sign of seasonality. This shows the usefulness of the calculation of $R(\tau)$ for noisier data, for which the periodicity is not so evident in the original values. In the case of random or constant data no periodicity was seen in the autocorrelation. Figure 9 also displays the results of $R(\tau)$ for the population parameters $\left(D, H^{\prime}, S\right.$ and $\left.J^{\prime}\right)$.

\section{Cross-correlations}

Although we calculated $R_{y z}(\tau)$ for all pairs of variables $(y, z)$, we decided to show the most useful ones to explain our general results (Fig. 10). Temperature appeared to be an important parameter determining population periodicity, represented by $S$ and $H^{\prime}$. We explored the influence of the seasonality with the detritivore and herbivore densities, as a consequence of the seasonal changes in food supply.

\section{DISCUSSION}

With the PCA results it is possible to distinguish two different environments. The first one is formed 

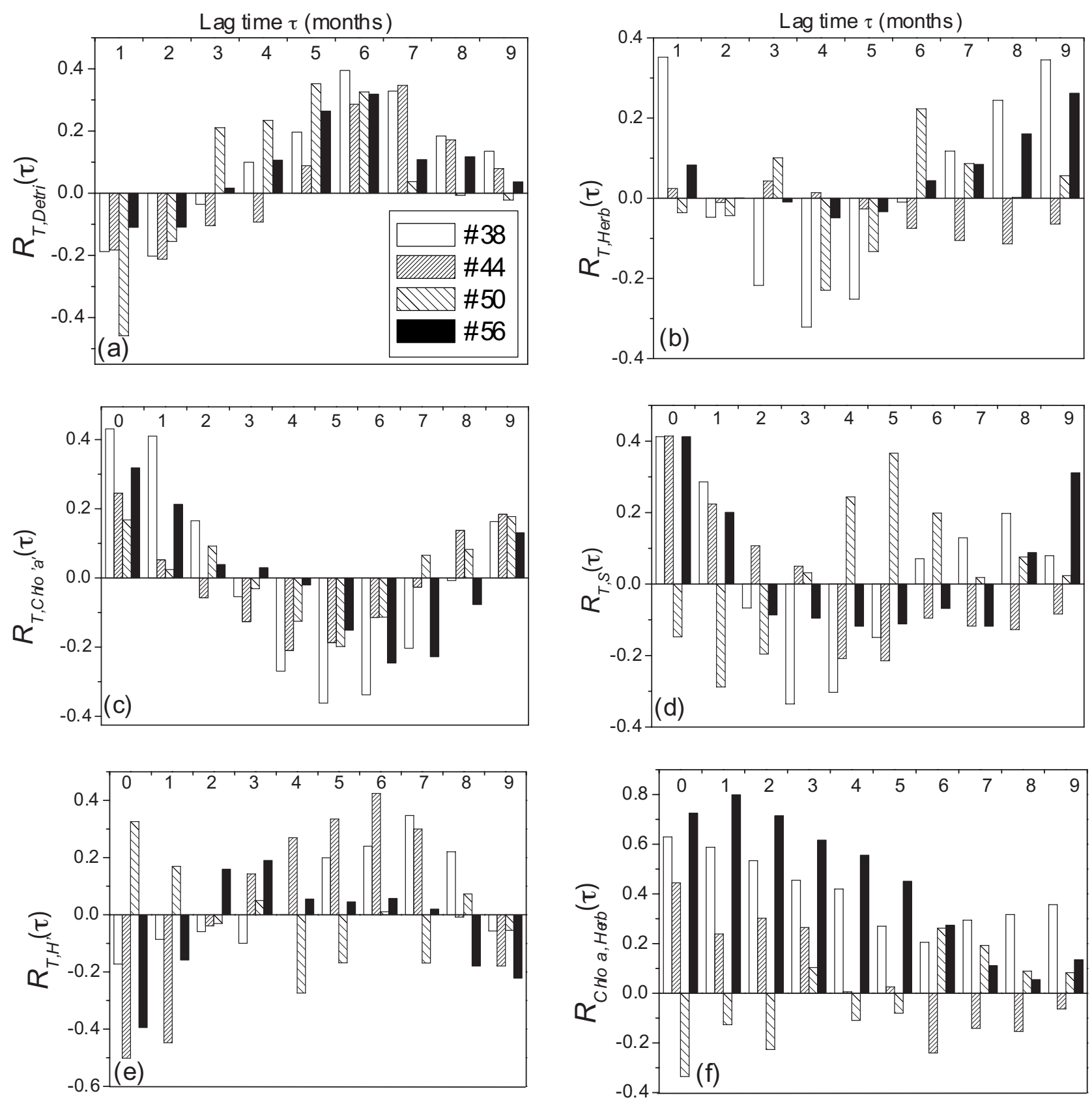

FIG. 10. - Cross-correlation functions (see Eq. (2) in the text) for some chosen pairs of variables. (a) Temperature x detritivore density; (b) Temperature $\mathrm{x}$ herbivore density; (c) Temperature x chlorophyll $a$; (d) Temperature $\mathrm{x}$ richness; (e) Temperature $\mathrm{x}$ diversity; (f) Chlorophyll $a \mathrm{x}$ herbivore density. Legend is shown in (a).

by Stations 44 and 50 and is related to the most contaminated rivers: da Lagoa and Grande de Ubatuba. The second group (Stations 38 and 56) is basically under the influence of the Acaraú and Indaiá rivers. This result is in agreement with the positive correlations between Group I and carbon concentration and nutrients of the pore water; and the negative correlation with $\mathrm{O}_{2}$ concentration and $\mathrm{pH}$ values. Moreover, the subgroup Ia (Station 50,
January and December) corresponds to the vacation periods when we observed a maximum of organic carbon in the sediments and lower percentages of dissolved oxygen in the bottom water. Group II showed high oxygen conditions, $\mathrm{pH}$ values around 8 and high Chl $a$ concentrations showing a less stressed environment. Within Group II the September samples of Stations 38 and 56 tended to form a new subgroup. Examining Figures 
3(a) and (b), we see an $\mathrm{NH}_{4}{ }^{+}$bw peak for Station 56 and $\mathrm{PO}_{4}{ }^{3-b w}$ peak for Station 38, followed by a general increase in $\mathrm{Chl} a$, which is also noted in the location of the September samples of Stations 44 and 50 in Group I. Furthermore, a considerable increase in total foraminiferal density was observed at Stations 38 and 56. An interesting point is that Group I was basically dominated by detritivore species (especially B. elegantissima, see Table 1), probably due to carbon and pore water phosphate enrichment, which was an important contribution in the first eigenvalue of PCA (axis I). Similarly, Group II was mostly populated by herbivore species (especially A. tepida, Murray (1991)), whereas the PCA showed a positive correlation with Chl $a$ and column water nutrients. The total foraminiferal densities were in agreement with this segregation, since Group II was much more populated than Group I, which revealed the most stressful conditions.

Seasonally, the nMDS analysis segregated the stations into two or three main groups according to the composition of the fauna throughout the studied year (see Fig. 8). This ordination analysis indicated a seasonal change in the station grouping based on foraminiferal distribution. A fairly homogeneous station group appeared in the autumn/winter period. It is also possible to observe two group separations that are very similar to that seen in the PCA. A significant change appeared in the spring period. The Station 50 in November is almost azoic, appearing isolated in the diagram. On the opposite diagonal side a group of three samples that are dominated by A. tepida can be seen. The middle group showed a more homogeneous species distribution. In summer the nMDS diagram dispersion was quite evident. The January and February samples at Station 50 showed very low densities, possibly as a consequence of low $\mathrm{pH}$ and $\mathrm{O}_{2}$ concentrations as well as the high $\mathrm{NH}_{4}{ }^{+}$concentration in the pore water. According to Bricker et al. (2003), $\mathrm{O}_{2}$ concentrations $>1.4$ and $\leq 3.5 \mathrm{ml} / \mathrm{L}^{-1}$ may cause biological stress. Thus, the simultaneous action of these abiotic factors probably makes the environment inhospitable for foraminiferal fauna development. On the other side of the diagram, the samples of Stations 50 and 56 of March share local blooms of Pararotalia cananeiaensis, positively correlated to the $\mathrm{O}_{2}$ concentration (see Fig. 2c and Table 2). All of these aspects are evidence of the rapid foraminiferal response to the abiotic disturbances.
As a rule, Stations 38 and 56 showed the highest densities of foraminifera, represented basically by hyaline species and dominated by Ammonia tepida. The high density of $A$. tepida is consistent with the results of other authors, who have pointed out its ability to tolerate lower salinities (Walton and Sloan, 1990). Debenay et al. (2001) stated that the growth of this species may be favoured by a temporary decrease in water salinity and by input of nutrients, which are both clearly observed at these stations (Table 1, Fig. 6e). Nevertheless, in this case, the low salinity is similar for all sites, and may not be used to justify the different distribution among the four studied sites. It is known that an increase in nutrient concentrations usually implies in an increase in primary producers, which results in an important feeding source for herbivore foraminiferal fauna, such as A. tepida (Erskian and Lipps, 1987; Murray and Alve, 2000). A positive correlation between A. tepi$d a$ densities and Chl $a$ concentration was shown by the Pearson correlation (0.61, see Table 2). According to Hohenegger et al (1989), A. tepida shows a strong preference for Cyanobacteria and avoids certain abundant diatoms. Similarly, a positive correlation was also observed in the cross-correlation $R_{\text {Chlo a,Herbivores }}(\tau)$ at Stations 38,44 and 56 for lag times of at least 3 months. In contrast, Station 50 was dominated by detritivore species, which explains its negative $R_{\text {Chlo a,Herbivores }}(\tau)$ coefficient.

Stations 44 and 50 contained mainly hyaline species, Buliminella elegantissima being the dominant one. However, other contributions of agglutinant and porcelanaceous species were also found. $B$. elegantissima showed a positive correlation with carbon concentration and nutrient pore water concentrations, indicating their preference for organic enriched environmental conditions, similarly to the observations of Setty (1982), Murray (1991) Bonetti (2000), and Burone and Pires-Vanin (2006).

Figure 7 represents the mean annual behaviour of the analysed stations. Stations 38 and 56 showed low diversity and evenness values, which are closely related to the A.tepida dominance. Although this dominance appears to be almost constant yearround, there are a few A. tepida peaks (strongly contributing to $D$, see Figure 6 and Table 1) that were linked to Chl $a$ maximum concentrations. Although we noticed the presence of juvenile individuals throughout the year, their presence increased in months of higher temperature, which is in agreement with former observations (Jones and Ross, 
1979). All these features may be seen as a result of a high adaptability of $A$. tepida to survive in under unstable environments.

An interesting point is the fact that the mean diversity (Fig. 7) is approximately homogeneous among all sites, and Stations 44 and 50 showed slightly higher mean diversity values than Stations 38 and 56, despite their low densities. In fact, for Station 50 the density would be even lower if it were not for a $P$. cananeiaensis peak in March. In this case, the high diversity does not lead to a healthy environment, since the extremely low foraminiferal densities demonstrate harmful conditions for fauna reproduction and growth. Actually, there were few moments with fewer than 50 individuals at Station 50. The $H^{\prime}$ index must therefore be used with care, because a sample with just a few individuals equally distributed among few species has higher diversity than a sample with many individuals of only one species, but the latter may be more appropriate for reproduction and growth (Burone et al. 2006). Thus, there is a major difference between the living dominant species of these two pairs of stations: Stations 38-56 with the herbivore A. tepida and Stations 4450 with the detritivore $B$. elegantissima. This evidences the organic enrichment at Stations 44 and 50. Furthermore, the abiotic factors measured also indicate higher anthropogenic contamination at Stations 44 and 50 (see Fig. 5). These results are in agreement with Pearson and Rosenberg (1978), who observed that an excess supply of organic material may lead to a collapse of the benthic community. Most investigations have reported the presence of an azoic zone or an area with extremely low abundance as a consequence of low oxygen and $\mathrm{pH}$ values (Clark, 1971; Boltovskoy and Wright, 1976; Alve, 1995). In the literature, A. tepida and B. elegantissi$m a$ are considered resistant or tolerant to the pollutants (see for example Yanko et al., 1999). Our results show that $B$. elegantissima is more resistant than A. tepida, indicating the spatial distribution of both dominant species.

We decided to calculate the cross-correlation function for $\mathrm{T}$ since it is a strong parameter that varies equally in time for all stations, so any differences in the population responses among the stations must be attributed to other factors. In Figure 10(a) a seasonal behaviour of the detritivore density is clear for all stations. We observe a negative maximum for small lag times and a positive maximum for a lag time around 6 months. This is probably due to the time needed for organic matter to decompose. The behaviour is almost opposite to that of herbivores, shown in Figure 10(b), but in this case the seasonality is not so evident for all stations. As for Station 38, a periodicity of approximately 5 months is clear, but with an opposite phase. The strong positive maximum for $\tau=0$ means that an increase in $T$ leads to an increase in the herbivore species density at the same time. This is a clear consequence of the Chl $a$ increase, as seen in Figure 10(c), which shows the cross-correlation between $\mathrm{T}$ x Chl $a$, demonstrating a clear periodicity of approximately 6 months, very similar to Figure 10(b). As expected, the Chl $a$ follows temperature changes, as a consequence of light incidence. In the specific case of Ubatuba Bay, the increase in $\mathrm{T}$ is concomitant to the vacation period, and consequently to an increase in nutrients coming from the rivers, which stimulate phytoplankton organisms. A similar response of the $R_{T, C h l o ~ a}(\tau)$ and $R_{\text {T,Herb }}(\tau)$ observed at Station 38 would be expected in non-stressed environments. At Station 56 the behaviour is approximately the same, but the correlations are not so strong. Although this station is more confined and the Indaiá River is not so polluted, the bay's clockwise water circulation may transport contaminants from the other rivers. Nevertheless, Stations 44 and 50 do not show a clear response to temperature (or to Chl $a$ ), due basically to the low-density populations and high environmental instability.

Richness and diversity are also closely connected to temperature. In general, regions close to the equator show higher diversity and number of species than the poles (Odum, 1972). However, in an anthropogenic-affected environment this effect may be masked. Furthermore, in micro-ecosystem analysis it is not possible to infer strong correlations between $\mathrm{T}$ and $\mathrm{S}$, and other factors must be taken into account. In Figures 10(d) and (e) it is seen that $R_{T, S}(\tau)$ and $R_{T, H},(\tau)$ have an opposite phase for all stations. Stations 38,44 and 56 have a positive maximum for $\tau \cong 0$ in the $R_{T, S}(\tau)$ curve, whereas Station 50 has a negative maximum. Once more, Stations 38 and 56 show a more evident seasonal pattern (of 4 or 6 months), whereas Stations 44 and 50 show different responses to their stressing conditions, such as very low $\mathrm{pH}$ and $\mathrm{O}_{2}$ content. The response of diversity to temperature occurs with the opposite phase, which is a consequence of the dominance of A.tep$i d a$ and $B$. elegantissima. These results for the time response analysis are in agreement with the mean annual results discussed above. 
Completing our temporal analysis, we briefly discuss the results of the autocorrelation coefficient for $T, D, S, J$ ' and $H^{\prime}$. Usually, for a good time series analysis an observation time much longer than the period one wants to analyse is necessary. This condition implies a high statistical significance for all lag times within the period analysed. Unfortunately, our data set extends for just one year, which limits our precision for high lag times. However, in cases where the observed data oscillate rapidly, it is possible to distinguish periods of the order of 2 to 6 months even in a short set of data such as ours. As pointed out above, the 6-month period of $R_{T}(\tau)$ is evidence of the periodic behaviour of the original data, basically due to seasonality. As seen in the other curves, no periodicity is found for the population parameters. This is due to the many different abiotic parameters that are not correlated in time, and are acting on the foraminiferal fauna. It must be emphasised that non-periodic does not mean random, but simply a result of the out-of-phase inputs of the abiotic components.

\section{CONCLUSIONS}

In this work we have studied benthic foraminiferal variability over a period of thirteen months at four coastal stations, each of which is basically influenced by one river. Geochemical and population parameters allowed the sites to be separated into two groups according to their degree of stress. Stations 38 and 56 were the most productive, having higher densities, with a high dominance of $A$. tepida and less stressful chemical conditions. These features are a consequence of the nutrient enrichment from the less polluted rivers. The Acaraú and Indaiá Rivers do not cross the urban zone and are not strongly affected by sewage. The high density observed at these stations is a biological effect that is in agreement with previous studies on the influence of domestic waste and organic enrichment on the benthic foraminiferal population (Yanko et al., 1994; Samir and El-Din, 2001; Burone et. al., 2006). On the other hand, Stations 44 and 50 are less productive, having almost azoic moments, and are dominated by $B$. elegantissima, which is typical of organic-enriched environments.

At Station 50, the low oxygen concentrations and $\mathrm{pH}$ values provide a high-stressed zone for the biota establishment. The low population density at
Stations 44 and 50 near the da Lagoa and Grande de Ubatuba Rivers may be correlated to the rivers' water quality. The excess of organic matter and nutrients makes the environment uninhabitable for most foraminiferal species. As a natural consequence of organic matter degradation, the $\mathrm{O}_{2}$ rate consumption and acidification are high. As a general comparison, it was possible to identify that Station 38 is less affected by environmental stress. This is due to its strong marine influence, since the water circulation is clockwise and the Acaraú River is the least polluted one.

The dominance of Ammonia tepida at Stations 38 and 56 is closely related to food abundance, as reflected in the Chl $a$ content. In our study area, $A$. tepida did not show resistance to low $\mathrm{O}_{2}$ concentrations and extremely acid $\mathrm{pH}$ values. $B$. elegantissi$m a$ appeared as an opportunist species at Stations 44 and 50 , since it is naturally infaunal and detritivore, occupying the niche left by A. tepida. Although $A$. tepida and B. elegantissima are considered resistant to contamination, B. elegantissima appears to be more opportunistic or resistant. A confirmation of these hypotheses will come from core analysis for the same sites, which have been made and will be the subject of further work.

As seen in the annual average values, the species diversity did not seem to be a good indicator of environmental health in places with high dominances or low densities, but density and richness could be used as evidence of local productivity and environmental conditions. The annual average results for the population parameters showed an interesting discrepancy between richness and diversity, a consequence of occasional dominance of some opportunist species (e.g. A tepida and B. elegantissima), which would not be observed in a single field sampling. It is important to note that the lack of replicate samples could affect some interpretations concerning the differences among locations, since the replicates could smooth over possible patches in foraminiferal distribution.

The annual monitoring showed that the anthropogenic effect is stronger in the austral summer period, when there is a massive increase in tourism, so the sewage input by the rivers in the Ubatuba Bay also increases.

It is clear that our results support the importance of time series analysis. The use of the cross-correlation seems to be a good tool for analysing the influence of abiotic parameters on the temporal evolution 
of the foraminiferal fauna. Thus, this mathematical tool complements other statistical analysis, like nMDS and PCA, bestowing more attention on seasonal environmental changes and the consequent seasonal biotic response. Thus, it is important for future monitoring work to extend through periods longer than a single year. A possible future utilisation of the cross-correlation function lies in the analysis of the influence of the water circulation upon the foraminiferal population dynamics, since the contribution of one river may affect not only its corresponding station, but others as well if some time interval is considered.

\section{ACKNOWLEDGEMENTS}

This work was supported by the Fundação de Amparo à Pesquisa do Estado de São Paulo (FAPESP, Brazilian agency) through a doctoral fellowship (Proc. $N^{\circ}$ 97/12493-7) provided to L.B. Thanks are extended to the Oceanographic Institute of the University of São Paulo for providing field and laboratory facilities.

\section{REFERENCES}

Abessa, D.M de S. and L. Burone. - 2003. Toxicity of sediments from the rivers situated in Ubatuba Bay (SP, Brazil). O Mundo da Saúde. 27(4): 564-569.

Alve, E. - 1991. Benthic foraminifera reflecting heavy metal pollution in Sorjord, Western Norway. J. Foraminifer. Res., 34: $1641-1652$

Alve, E. - 1995. Benthic foraminifera response to estuarine pollution. A review. J. Foraminifer. Res., 25 (3): 190-203.

Armynot Du Châtelet, E., J-P. Debenay and R. Soulard. - 2004. Foraminiferal proxies for pollution monitoring in moderately polluted harbors. Mar. Pollut. Bull., 127: 27-40.

Boltovskoy, E., D.B Scott and F.S. Medioli. - 1991. Morphological variations of benthic foraminiferal test in response to changes in ecological parameters: a review. J. Paleontol., 65(2): 175- 185.

Boltovskoy, E. and R. Wright. - 1976. Recent Foraminífera. W. Junk (ed) The Hague.

Bonetti, C. - 2000. Foraminíferos como bioindicadores do gradiente de estresse ecológico em ambientes costeiros poluídos. Estudo aplicado ao sistema astuarino de Santos-São Vicente $(S P$, Brasil). Ph. D. thesis, Instituto Oceanográfico, Univ. de São Paulo, São Paulo.

Bray, J.R. and J. T. Curtis. - 1957. An ordination of the upland forest communities in southern Wisconsin. Ecol. Monogr., 27: 325-349.

Bricker, S.B., J.G. Ferreira and T. Simas. - 2003. An integrated methodology for assessment of estuarine trophic status. Ecol. Model. 169: 39-60.

Burone, L., 2002. Foraminíferos Bentônicos e Parâmetros físicoquímicos da Enseada de Ubatuba, São Paulo: Estudo Ecológico em uma área com Poluição Orgânica. Ph. D thesis, Instituto Oceanográfico, Univ. de São Paulo, São Paulo.

Burone, L., E. Braga, P. Valente and A.M.S. Pires-Vanin. - 2005 A Chemical Analysis of sediment pore water in oxygen-free atmosphere: application to a contaminated area. Braz. J. Oceanogr. 53(1-2): 69-74.
Burone, L., P. Muniz, A.M.S. Pires-Vanin and M. Rodrigues. 2003. Spatial distribution of organic matter in the surface sediments of Ubatuba Bay (Southeastern - Brazil). An. Acad. Bras. Ciênc. 75(1): 1-14.

Burone, L. and A.M. S. Pires-Vanin. - 2006. Foraminiferal assemblages in the Ubatuba Bay, Southeastern Brazilian coast. Sci. Mar., 70(2): 203-217.

Burone, L., N. Venturini, P. Sprechmann, P. Valente and P. Muniz. 2006. Foraminiferal responses to polluted sediments in the Montevideo coastal zone, Uruguay. Mar. Pollut. Bull. 52: 61-73.

CETESB (Companhia de Tecnologia de Saneamento Ambiental).1996. Relatório de Balneabilidade das Praias Paulistas, 1995. Secretaria do Meio Ambiente, São Paulo, Brazil.

CETESB (Companhia de Tecnologia de Saneamento Ambiental). 2000. Relatório de Balneabilidade das Praias Paulistas, 1999. Secretaria do Meio Ambiente, São Paulo, Brazil.

Clark, D.F. - 1971. Effects of aquaculture outfall on benthonic foraminifera in Clam Bay, Nova Scotia: Marit. Sedim., 7: 76-84.

Clarke K.R. and R.M. Warwick. - 2001. Change in marine communities: an approach to statistical analysis and interpretation. Plymouth Marine Laboratory, Plymouth.

Debenay, J.P., E. Geslin, B.B. Eichler, W. Duleba, F. Sylvestre and P. Eichler. - 2001. Foraminiferal assemblages in a hypersaline lagoon Araruama (RJ) Brazil. J. Foraminifer. Res., 31(2): 133151.

Erskian, M.G. and J.U.H. Lipps.- 1987. Population dynamics of the foraminiferan Glabratella ornatissima (Cushman) in northern California: J. Foraminifer. Res., 17: 240-256.

Grasshoff, K., M. Ehrhardt and K.V. Kremeling. - 1983. Methods of seawater analysis. Verlag Chemie, Weinheim.

Hohenegger, J., W. Piller and C. Baal. - 1989. Reasons for spatial microdistributions of foraminifers in an intertidal pool (Northern Adriatic Sea). Mar. Ecol., 10(1): 43-78.

Jones, G.D. and C.A. Ross. - 1979. Seasonal distribution of foraminifera in Samish Bay, Washington. J. Paleont., 53: 245- 257.

Jorgensen, B. - 1996. Material flux in the sediment. In: Coastal and estuarine studies, (ed.), By B. Jorgensen and K. Richardson. American Geophysical Union.

Kovach, W.L. - 1999. MVSP - A multivariate statistical package for windows, ver. 3.1. Kovach Computing Services, Pentraeth, Wales.

Kruskal, J.B. and M. Wish. 1978. Multidimensional scaling. California Sage, Beverly Hills.

Loeblich, A.R. and H. Tappan. 1988. Foraminiferal Genera and their Classification: Van Nostrand Reinhold, New York.

Lorenzen, C.J. - 1967. Determination of chlorophyll and pheopigments: Spectrofotometric equations. Limnol. Oceanogr., 12: 343- 346.

Mahiques, M.M., M.G. Tessler and V.V. Furtado. - 1998. Characterization of energy gradient in enclosed bays of Ubatuba region, South-eastern, Brazil. Est. Coast. Shelf Sci., 47: 431-446.

Muniz, P. - 2003. Comunidades macrobênticas como indicadoras da qualidade ambiental de ecossistemas costeiros rasos: estudo de caso - Enseada de Ubatuba (SP, Brasil). Ph. D. thesis, Instituto Oceanográfico, Univ. de São Paulo, São Paulo.

Murray, J.W. - 1991. Ecology and Paleoecology of Benthic Foraminifera. Longman, Harlow.

Murray, J.W. and E. Alve. - 2000. Major aspects of foraminiferal variability (standing crop and biomass) on a monthly scale in an intertidal zone. J. Foraminifer. Res., 30 (3): 177-191.

Odum, E.P. - 1972. Ecología. Editora Nueva Editorial Interamericana, S. A., México.

Pearson, T.H. and R. Rosenberg. - 1978. Macrobenthic succession in relation to organic enrichment and pollution of marine environment. Oceanogr. Mar. Biol Annu Rev., 16: 229-311.

Pielou, E.C. - 1975. Ecological diversity. John Wiley, New York.

Reisig, J.M. - 1960. Foraminiferal ecology around ocean outfalls off southern California. Waste Disposal in the Marine Environment. Pergamon Press. London.

Samir, A.M. and A.B.El-Din. - 2001. Benthic foraminiferal assemblages and morphological abnormalities as pollution proxies in two Egyptian bays. Mar. Micropaleontol., 41: 193-227.

Scott, D.B., F.S. Medioli, C.T. Shafer. - 2001. Monitoring of Coastal environments using Foraminifera and Thecamoebian indicators. Cambridge University Press. 
Setty, M.G.A.P. - 1982. Pollution effects monitoring with foraminifera as indices in the Thana Creek, Bombay area: Indian J. Mar. Sci., 18: 205-209.

Shannon, C.E. and W.W. Weaver. - 1963. The mathematical theory of communication. University of Illinois Press, Urbana.

Strickland, J.D.H. and T.R. Parsons. - 1968. A practical handbook of sea-water analysis. Bull. Fish. Res., Board, Canada., 169: 1-311.

Suguio, K. - 1973. Introdução à sedimentologia. São Paulo, Edgar Blücher/ Editora da Universidade de São Paulo (EDUSP).

Tréguer, P. and P. Le Corre. - 1975. Manuel d' analysis des sels nutritifs dans l'eau de mer. 2ème éd. Brest, Université de Bretagne Occidentale.

Turner, S.J., S.F. Thrush, R.D. Pridmore, J.E. Hewitt, V.J. Cummings, and M. Maskery. - 1995. Are soft-sediment communities stable? An example from a windy harbour. Mar. Ecol. Prog. Ser., 120: 219-230.

Walton, W.R. - 1952. Techniques for recognition of living foraminifera. Contrib. Cushman Found. Foram. Res., 3: 56-60.

Walton, W.R. and B. Sloan. - 1990. The genus Ammonia Brünnich. 1972: its geographic distribution and morphological variability.
J. Foraminif. Res., 20: 128-156.

Watkins, J.G. - 1961. Foraminiferal ecology around the Orange County, California, ocean sewer outfall. Micropaleontology, 7 : 199-206.

Wilson, B. and R.A. Dawe. - 2006. Detecting seasonality using time series analysis: comparing foraminiferal population dynamics with rainfall data. J. Foraminif. Res., 36:108-115.

Yanko, V., A. Arnold and W. Parker. - 1999. Effect of marine pollution on benthic foraminifera. In: B.K. Sen Gupta (ed.), Modern Foraminifera, pp. 217-235. Kluwer Academic Publishers, Dordrecht.

Yanko, V., J. Kronfeld and A. Flexer. - 1994. Response of benthic foraminifera to various pollution sources: implications for pollution monitoring. J. Foraminif. Res., 24(1): 1-17.

Zalesny, E.R. - 1959. Foraminiferal ecology of Santa Monica Bay. California. Micropaleontology, 5: 101- 126.

Scient. ed.: M.P. Olivar.

Received February 12, 2007. Accepted September 3, 2007.

Published online November 9, 2007. 